\title{
Expression Levels of the CA9, WT1, and PRAME Genes and Genotyping-Associated Antigens for the Diagnosis and Prognosis of Colorectal Cancer
}

\author{
Tabark S Jassim ${ }^{10}$ \\ 1 Prosthodontic Technology Department, Dijlah University College, \\ Baghdad, Iraq \\ Address for correspondence Tabark S Jassim, PhD, Prosthodontic \\ Technology Department, Dijlah University College, Baghdad, \\ Zipcode: 10022, Baghdad, Iraq (e-mail: rawaqjasim@gmail.com). \\ J Coloproctol 2022;42(2):120-125.
}

\begin{abstract}
Keywords

- colorectal cancer

- tumor-associated antigens

- real-time polymerase chain reaction

- CA9

- WT1

- PRAME

Background Colorectal cancer (CRC) is the third most prevalent type of cancer worldwide, and is one of the major health problems in Asia, Africa, Europe, and America. The tumor antigens recently are of interesting indicators as diagnostic and prognostic tools, The aim of the present study is to detect the expression levels of carbonic anhydrase IX (CA9), the Wilms tumor gene (WT1), and the preferentially expressed antigen in melanoma (PRAME) in the peripheral blood of CRC patients in comparison with healthy controls.

Methods A prospective case-control study of CRC patients was conducted. We included 25 newly-diagnosed CRC eligible patients and obtained peripheral blood samples of them as well as 10 blood samples from the control group. All samples were then submitted to deoxyribonucleic acid (DNA) extraction and a molecular study through real-time polymerase chain reaction (PCR).

Results The CRC group consisted of 15 (60\%) female and 10 (40\%) male patients with a mean age of $50.52 \pm 9.8$ years, while the control group included 4 (40\%) female and 6 (60\%) male patients with a mean age of $47.7 \pm 7.9$ years. The CRC group, 24 (96\%) of patient samples were CA9-positive with strong statistically significant differences ( $p<0.00001$; sensitivity: 96\%; specificity: 90\%). Regarding the WT1 gene, there were $11(44 \%)$ positive samples in the CRC group, with no statistically significant differences ( $p=0.055$; sensitivity: $44 \%$; specificity: $90 \%$ ). The PRAME gene was positive in $9(36 \%)$ samples in the CRC group, with no statistically significant differences ( $p=0.357$; sensitivity: $36 \%$; specificity: $80 \%$. Among CA9 (24 patients; $96 \%$ ) of patients with CRC expressed positive results, in WT1 11(91.6\%) CRC patients expressed gene, and in PRAME gene, 9 patients with CRC (81.8\%) expressed positive results.

Conclusion Overexpression of the CA9 gene in CRC of high sensitivity and specificity to be used as a tool to discriminate CRC from benign associate with high accuracy compare to WT1 and PRAME genes.
\end{abstract}

received

August 7, 2021

accepted after revision

October 25, 2021

published online

November 23, 2021
DOI https://doi.org/

10.1055/s-0041-1741323.

ISSN 2237-9363.

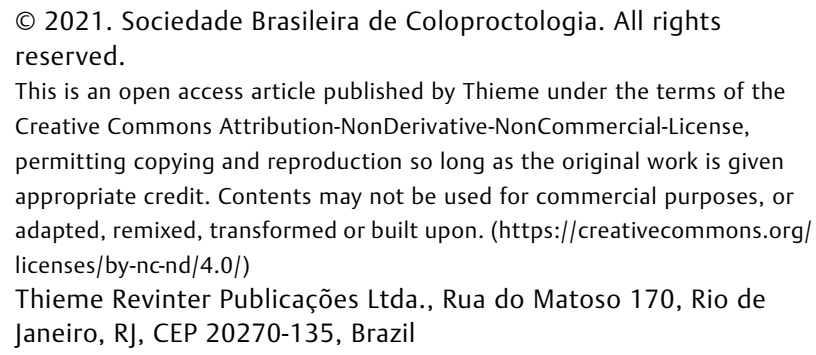

(c) 2021. Sociedade Brasileira de Coloproctologia. All rights reserved.

This is an open access article published by Thieme under the terms of the Creative Commons Attribution-NonDerivative-NonCommercial-License, permitting copying and reproduction so long as the original work is given appropriate credit. Contents may not be used for commercial purposes, or adapted, remixed, transformed or built upon. (https://creativecommons.org/ licenses/by-nc-nd/4.0/)

Thieme Revinter Publicações Ltda., Rua do Matoso 170, Rio de Janeiro, RJ, CEP 20270-135, Brazil 


\section{Introduction}

In 2018, more than 2 million new cases of colorectal cancer (CRC) were recorded worldwide, and caused around 1 million deaths that year. ${ }^{1-4}$ This type of cancer ranks third in terms of incidence and second in terms of mortality. ${ }^{1}$ Tumorassociated antigens (TAAs) are molecules and proteins expressed by tumor cells, and they may act as cancer markers. ${ }^{2}$ In cases of CRC, TAAs are underexpressed in normal tissue but are overexpressed or mutated in tumor cells.

A member of the carbonic anhydrase family, carbonic anhydrase IX (CA9) is one of the genes that is overexpressed in tumor cells; it is is a membrane protein that regulates cell proliferation in response to hypoxia. ${ }^{5,6}$ In 2006, Talvinen et al. ${ }^{7}$ found that CA9 was the most up-regulated gene in cases of CRC through a complementary DNA (CDNA) microarray.

The Wilms tumor (WT1) gene is one of the genes involved in growth regulation and/or differentiation of cells. ${ }^{8,9}$ Previous studies have demonstrated that WT1 is expressed in cancer cells derived from different types of cancers, including CRC, ${ }^{10}$ leukemia, ${ }^{11}$ breast cancer, ${ }^{12,13}$ non-small-cell lung carcinoma (NSCLC), ${ }^{14}$ soft-tissue sarcoma (STS), ${ }^{15}$ and head and neck squamous cell carcinoma (HNSCC). ${ }^{16}$

The preferentially expressed antigen in melanoma (PRAME) gene is detected in melanoma, but its expression is absent or low in cases of CRC. ${ }^{17}$ The PRAME gene is expressed in many different cancers, and its expression correlates with prognosis and survival. It is expressed in NSCLCs, breast carcinomas, renal cell carcinomas (RCCs), head and neck cancers, Hodgkin lymphomas (HLs), sarcomas, Wilms tumors, and medulloblastomas. ${ }^{17}$

The present work was designed to assess the diagnostic and prognostic value of the CA9, WT1, and PRAME genes in cases of CRC.

\section{Methods}

\section{Study Design and Setting}

A prospective case-control study with CRC patients was conducted in the National Center of Cancer from March to December 2020. The following data were collected: age, gender, family history, tumor sites, tumor differentiation, and tumor stages. All patients were histologically diagnosed with CRC. The control group who referred to this center for screening purposes due to negative colonoscopies. Then all cases were submitted to molecular analysis.

\section{Clinical Samples}

Peripheral blood samples were collected from the 25 eligible patients newly-diagnosed with CRC in different stages, as well as from 10 patients in the control group. The samples had been sent to and preserved at the genetic laboratory of the National Center of Cancer. In total, $2 \mathrm{~mL}$ from each sample were put in ethylenediaminetetraacetic acid (EDTA) tubes. All samples were then submitted to DNA extraction and a molecular study through real-time polymerase chain reaction (PCR).

\section{Ethics Consideration}

All patients signed the informed consent form for the present study, and approval was obtained from the Ethics in Research Committee of Dijlah University College.

\section{DNA Extraction and Real-time PCR}

The total genomic DNA of the samples from the CRC and control groups was extracted from the peripheral blood using the salting-out method, ${ }^{18}$ following the protocol provided by the manufacturer. Beta-catanin/Tcf is the constitutive gene, a double-stranded 15-nucleotide oligomer composed from first forward set contained CCCT T TGATCT TACC, and the second reverse set CCCT T TGGCCT TACC. ${ }^{19}$

These were analyzed using specific primers, which were designed using the Gene Runner software, version 4.0.9.68 Beta ( - Table 1 ). The quantitative real-time PCR assay was performed in duplicate using the Applied Biosystems PCR Systems (Thermo Fisher Scientific, Waltham, MA, US). Synthesis of the suitable size PCR products were visualized by agarose gel electrophoresis. Genotyping was performed using the PCR-restriction fragment length polymorphism (PCR-RFLP) analytical method. The real-time PCR program is described and illustrated in -Table 2 and -Fig. 1 respectively.

Table 1 Sequences of the primers used in the present study

\begin{tabular}{|l|l|l|l|}
\hline \multicolumn{2}{|l|}{ Primer } & Sequence & $\begin{array}{l}\text { Size } \\
\text { (base } \\
\text { pairs) }\end{array}$ \\
\hline \multirow{2}{*}{ CA9 } & Forward & $5^{\prime}$-GTGGAAGGCCACCGTTTC-3' & 1,546 \\
\cline { 2 - 3 } & Reversed & $5^{\prime}$-CTCGTCAACTCTGGCAAAGG-3' & \\
\hline \multirow{2}{*}{ WT1 } & Forward & $5^{\prime}$-AGGCTTTGCTGCTGAGGAC-3' & \multirow{2}{*}{1,962} \\
\cline { 2 - 3 } & Reversed & $5^{\prime}$-CAGGTCATGCATTCAAGCTG-3' & \\
\hline \multirow{2}{*}{ PRAME } & Forward & $5^{\prime}$-CTTTCCTCGAAGGCCACCT-3' & \multirow{2}{*}{1,479} \\
\cline { 2 - 3 } & Reversed & $5^{\prime}$-GTTATTGTGAGGACCTTTAACGA-3' & \\
\hline
\end{tabular}

Table 2 Real-time polymerase chain reaction program

\begin{tabular}{|l|l|l|l|l|}
\hline No & Steps & $\begin{array}{l}\text { Temperature } \\
\left(\mathrm{C}^{\circ}\right)\end{array}$ & Time & Cycles \\
\hline I & $\begin{array}{l}\text { Initial } \\
\text { denaturation }\end{array}$ & 50 & 2 minutes & 1 \\
\hline II & Denaturation & 95 & 10 minutes & 1 \\
\hline III & Annealing & 95 & 15 seconds & \multirow{2}{*}{30} \\
\cline { 3 - 4 } & 65 & 60 seconds & \multirow{2}{*}{} \\
\cline { 3 - 4 } & & 72 & 60 seconds & \\
\hline IV & $\begin{array}{l}\text { Final } \\
\text { extension }\end{array}$ & 95 & 15 seconds & 1 \\
\hline
\end{tabular}




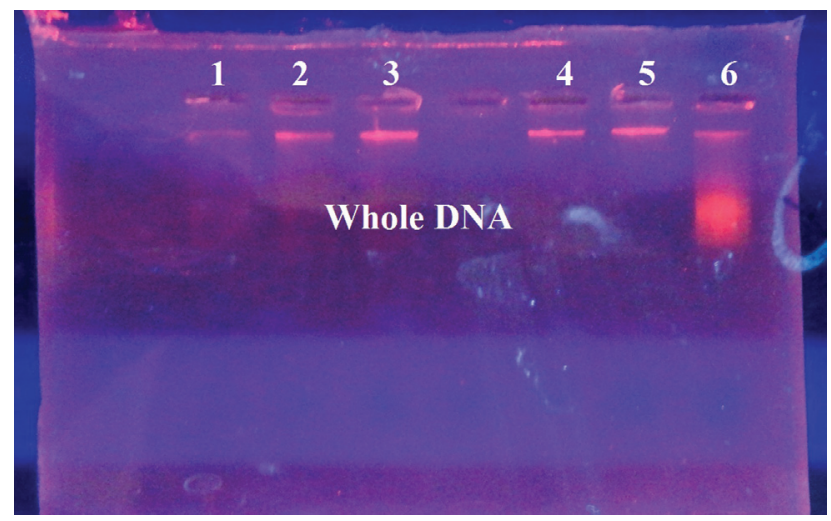

Fig. 1 Electrophoresis for the extraction of genomic DNA from samples in $1 \%$ agarose gel.

\section{Statistical Methods}

All data were analyzed using the Statistical Package for the Social Sciences (SPSS Statistics for Windows, IBM Corp., Armonk, NY, US) software. Frequency tables were analyzed using the Wilcoxon rank sum test to compare the two groups in a non-parametric pattern. The numerical variables were expressed as means and standard deviations (SDs). A twosided $p$-value $\leq 0.05$ was considered statistically significant.

\section{Results}

The CRC group consisted of 15 (60\%) females and 10(40\%) male patients with mean age of $50.52 \pm 9.8$ years, while the control group included 4 (40\%) female and $6(60 \%)$ male patients with mean age of $47.7 \pm 7.9$ years. Only 2 (8\%) patients in the CRC group and $1(10 \%)$ individual in the control group had family history positive of CRC. The rectosigmoid was the most common site, reported in 13 (52\%) patients, the rectum in 10 (40\%) patients, and the anus and rectum in 2 (8\%) individuals. Regarding tumor differentiation, it was classified as moderate (52\%), well (44\%), and poor (4\%). Regarding the tumor, lymph node, and metastasis (TNM) staging, T2N0, and T3N0 were the most common classes, each observed in 6 (24\%) patients. Metastasis were found in 4 (16\%) patients, and lymphovascular and regional invasions were observed in 12 (48\%) patients. Stage-II cancer was the most common, present in 12 (48\%) patients, as shown in - Table 3 .

Out of 25 cases of CRC, 24 (96\%) patients samples were CA9 positive, with strong statistically significant differences ( $p<0.00001$; sensitivity: $96 \%$; specificity: $90 \%$; positive predictive value [PPV]: 96\%; negative predictive value [NPV]: $90 \%)$. Regarding the WT1 gene, there were $44 \%$ of positive samples, with no statistically significant differences ( $p=0.055$; sensitivity: $44 \%$; specificity: $90 \%$; PPV: $91.67 \%$; NPV: 39.13\%). The PRAME gene was positive in 9 (36\%) CRC patients, with no statistically significant differences ( $p=0.357$; sensitivity: $36 \%$; specificity: $80 \%$; PPV: $81.82 \%$; NPV: $33.33 \%)$. As a result, the sensitivity and specificity of the CA9 gene were higher for the diagnosis and prognosis of CRC than the WT1 and PRAME genes, with an accuracy reaching 94.29\%, as shown in - Table 4. - Table 5 shows a comparison of the expression of TAAs of the CA9, WT1, and PRAME genes between the two study groups. Regarding the CA9 gene, 24 (96\%) patients in the CRC group and $1(4 \%)$ individual in the control group expressed positive results, with strong statistically significant differences $(p<0.0001)$. s for the WT1 gene, 11 (91.6\%) CRC patients and 1 (8.4\%) control expressed it, with strong statistically significant differences $(p<0.0001)$. In addition, $9(81.8 \%)$ patients in the CRC group and $2(18.2 \%)$ controls expressed the PRAME gene, with high statistically significant differences $(p<0.001)$. Gel electrophoresis of the PCR products of CRC patients were performed using the primers set for the CA9, WT1, and PRAME genes (forward and reversed) of DNA, as shown in - Fig. 2.

\section{Discussion}

The incidence of CRC is increasing annually worldwide. The demographics of the CRC group were similar to those of the patients in most of the studies conducted in Iraq, such as those by Radhi et al. ${ }^{20}$ in Al-Diwaniyah, by Alsafi et al. ${ }^{21}$ in Karbala, by Alshewered and Al-Naqqash ${ }^{2}$ and by Alrubaia et al. ${ }^{3}$ in Baghdad, but differed from the demographics found in the studies by Alhilfi et al. ${ }^{4}$ in Misan, and by Khalil et al. ${ }^{22}$ in Duhok. In Western countries, $8 \%$ of the CRC cases are recorded in patients younger than 40 years of age, whereas in Asia and Africa the rates range between $15 \%$ and $35 \%$ for the same age group. ${ }^{23-25}$

Early detection of CRC can improve the chance of a successful management and better prognosis. Tumor-associated antigens and autoantibodies have generated increasing interest as biomarkers for the development of innovative diagnostic and prognostic tools that have an effective role in the management of human cancers. ${ }^{26}$ Feitosa et al. ${ }^{27}$ concluded that genetic counseling and proper screening programs are essential tools for the early diagnosis and followup of cases of CRC.

In the present study, CA9 expression showed high sensitivity and specificity for the detection of CRC, with high accuracy (of up to $94.29 \%$ ). In fact, it can be used as a potential significant prognostic tool in CRC. These data implicate that the intensity of the CA9 expression seems to be a powerful independent prognostic factor, not confounded by the mode of treatment.

In a study, Korkeila et al. ${ }^{29}$ found no correlation between the expression of CA9 and other clinical or histopathological factors of CRC, since most of their patients had received radiotherapy with or without chemotherapy before operation, which may have had an influence on tumor size, stage, grade, and nodal status. Driessen et al. ${ }^{30}$ found a significant correlation between the WT1 gene and the grade, stage, and lymph node status of different kinds of tumors, while Epping and Bernards ${ }^{17}$ demonstrated that the lymph node status of patients was not directly associated with the PRAME gene.

In their study, Oji et al. ${ }^{31}$ demonstrated that the WT1 gene was overexpressed in the majority of the primary colorectal adenocarcinomas they examined, and it was the non-mutated, wild type. This result supported their hypothesis that the wild-type WT1 gene does play an oncogenic role in the 
Table 3 Clinical features of patients with colorectal adenocarcinoma (colorrectal cancer group: patients 1-25; control group: patients 26-35)

\begin{tabular}{|c|c|c|c|c|c|c|c|}
\hline ID & Age (years) & Gender & Family history & Tumor site & Differentiation & $\begin{array}{l}\text { Tumor, Node, } \\
\text { Metastasis } \\
\text { classification }\end{array}$ & Stage \\
\hline 1 & 36 & Female & Negative & Rectosigmoid & Well & $\mathrm{T} 2 \mathrm{NO}$ & II \\
\hline 2 & 54 & Female & Negative & Rectosigmoid & Moderate & $\mathrm{T} 2 \mathrm{NO}$ & II \\
\hline 3 & 51 & Male & Negative & Rectosigmoid & Well & $\mathrm{T} 2 \mathrm{~N} 2$ & III \\
\hline 4 & 44 & Female & Negative & Rectum & Moderate & T1N0 & 1 \\
\hline 5 & 60 & Male & Negative & Rectum & Well & T3N1M1 & IV \\
\hline 6 & 37 & Male & Negative & Rectosigmoid & Moderate & T3NO & II \\
\hline 7 & 29 & Male & Negative & Rectosigmoid & Moderate & T3N1 & III \\
\hline 8 & 53 & Male & Negative & Rectum & Well & T2NO & II \\
\hline 9 & 63 & Female & Negative & Rectum & Poor & T2N2M1 & IV \\
\hline 10 & 56 & Female & Negative & Rectum & Well & T3NO & II \\
\hline 11 & 39 & Female & Positive & Rectosigmoid & Well & T3N1 & III \\
\hline 12 & 55 & Female & Negative & Rectum & Moderate & T3NO & II \\
\hline 13 & 40 & Male & Negative & Rectosigmoid & Well & $\mathrm{T} 2 \mathrm{~N} 2$ & III \\
\hline 14 & 54 & Female & Negative & Rectosigmoid & Moderate & $\mathrm{T} 2 \mathrm{NO}$ & II \\
\hline 15 & 52 & Female & Negative & Rectosigmoid & Moderate & T3N1 & III \\
\hline 16 & 70 & Male & Negative & Rectosigmoid & Well & T3NO & II \\
\hline 17 & 62 & Female & Negative & Rectosigmoid & Moderate & T2N1M1 & IV \\
\hline 18 & 61 & Female & Negative & Anus and rectumal & Moderate & $\mathrm{T} 2 \mathrm{NO}$ & II \\
\hline 19 & 55 & Male & Negative & Rectum & Moderate & $\mathrm{T} 2 \mathrm{NO}$ & II \\
\hline 20 & 59 & Male & Negative & Rectosigmoid & Moderate & T3N2M1 & IV \\
\hline 21 & 48 & Female & Negative & Anus and rectum & Moderate & T3NO & II \\
\hline 22 & 47 & Male & Positive & Rectosigmoid & Moderate & $\mathrm{T} 2 \mathrm{~N} 1$ & III \\
\hline 23 & 47 & Female & Negative & Rectum & Well & T1N1 & III \\
\hline 24 & 50 & Female & Negative & Rectum & Well & T3NO & II \\
\hline 25 & 41 & Female & Negative & Rectum & Well & T3N1 & III \\
\hline 26 & 39 & Male & Negative & & & & \\
\hline 27 & 50 & Male & Negative & & & & \\
\hline 28 & 44 & Male & Negative & & & & \\
\hline 29 & 43 & Female & Negative & & & & \\
\hline 30 & 60 & Male & Negative & & & & \\
\hline 31 & 52 & Female & Negative & & & & \\
\hline 32 & 56 & Female & Negative & & & & \\
\hline 33 & 55 & Male & Negative & & & & \\
\hline 34 & 38 & Female & Positive & & & & \\
\hline 35 & 40 & Male & Negative & & & & \\
\hline
\end{tabular}

tumorigenesis of CRC. The results of the present study are in line with those of the study by Oji et al. ${ }^{31}$ since the WT1 was expressed in $44 \%$ of the CRC group, but without any statistical significance. Moreover, Oji et al. ${ }^{31}$ reported that the overexpression was observed in most of the patients examined by them, and this high frequency might indicate that the WT1 gene is one of the critical genetic events in tumorigenesis.
They reported that the analysis of the correlation between the expression of WT1 in colorectal hyperplastic mucosa, adenoma, and carcinoma, is of interest and importance. ${ }^{31}$

Many previous studies ${ }^{32-34}$ indicated that the expression of the PRAME gene is not significantly associated with relapse-free survival, tumor grade and size, and lymph node status in cases of CRC. These results may be due to 
Table 4 Gene expression results

\begin{tabular}{|c|c|c|c|c|}
\hline \multicolumn{2}{|c|}{$\begin{array}{l}\text { Tumor-associated } \\
\text { antigens }\end{array}$} & $\begin{array}{l}\text { Colorectal } \\
\text { cancer }\end{array}$ & $\begin{array}{l}\text { Control } \\
\text { group }\end{array}$ & \multirow[t]{2}{*}{$p$-value } \\
\hline & & \multicolumn{2}{|l|}{ N (\%) } & \\
\hline \multirow[t]{2}{*}{$C A 9^{\$}$} & Positive & $24(96)$ & $1(10)$ & \multirow[t]{2}{*}{$<0.00001$} \\
\hline & Negative & $1(4)$ & $9(90)$ & \\
\hline \multirow[t]{2}{*}{ WT1* } & Positive & $11(44)$ & $1(10)$ & \multirow[t]{2}{*}{0.055} \\
\hline & Negative & $14(56)$ & $9(90)$ & \\
\hline \multirow[t]{2}{*}{ PRAME ${ }^{\#}$} & Positive & $9(36)$ & $2(20)$ & \multirow[t]{2}{*}{0.357} \\
\hline & Negative & $16(64)$ & $8(80)$ & \\
\hline
\end{tabular}

Notes: ${ }^{\$}$ Sensitivity: $96 \%$; specificity: $90 \%$; positive predictive value (PPV): 96\%; negative predictive value (NPV): 90\%; accuracy: 94.29\%. *Sensitivity: 44\%; specificity: 90\%; PPV: 91.67\%; NPV: 39.13\%; accuracy: $57.14 \%$.

\#Sensitivity: 36\%; specificity: 80\%; PPV: 81.82\%; NPV: 33.33\%; accuracy: $48.57 \%$.
Table 5 Comparison of the expression of tumor-associated antigens of the CA9, WT1, and PRAME genes between the two study groups

\begin{tabular}{|l|l|l|l|}
\hline \multirow{2}{*}{$\begin{array}{l}\text { Tumor-associated } \\
\text { antigens }\end{array}$} & $\begin{array}{l}\text { Colorectal } \\
\text { cancer group }\end{array}$ & $\begin{array}{l}\text { Control } \\
\text { group }\end{array}$ & \multirow{2}{*}{-value } \\
\cline { 2 - 3 } & $\mathrm{N} \mathrm{( \% )}$ & \multicolumn{2}{|l|}{} \\
\hline CA9 & $24(96)$ & $1(4)$ & $<0.0001$ \\
\hline WT1 & $11(91.6)$ & $1(8.4)$ & $<0.0001$ \\
\hline PRAME & $9(81.8)$ & $2(18.2)$ & $<0.001$ \\
\hline
\end{tabular}

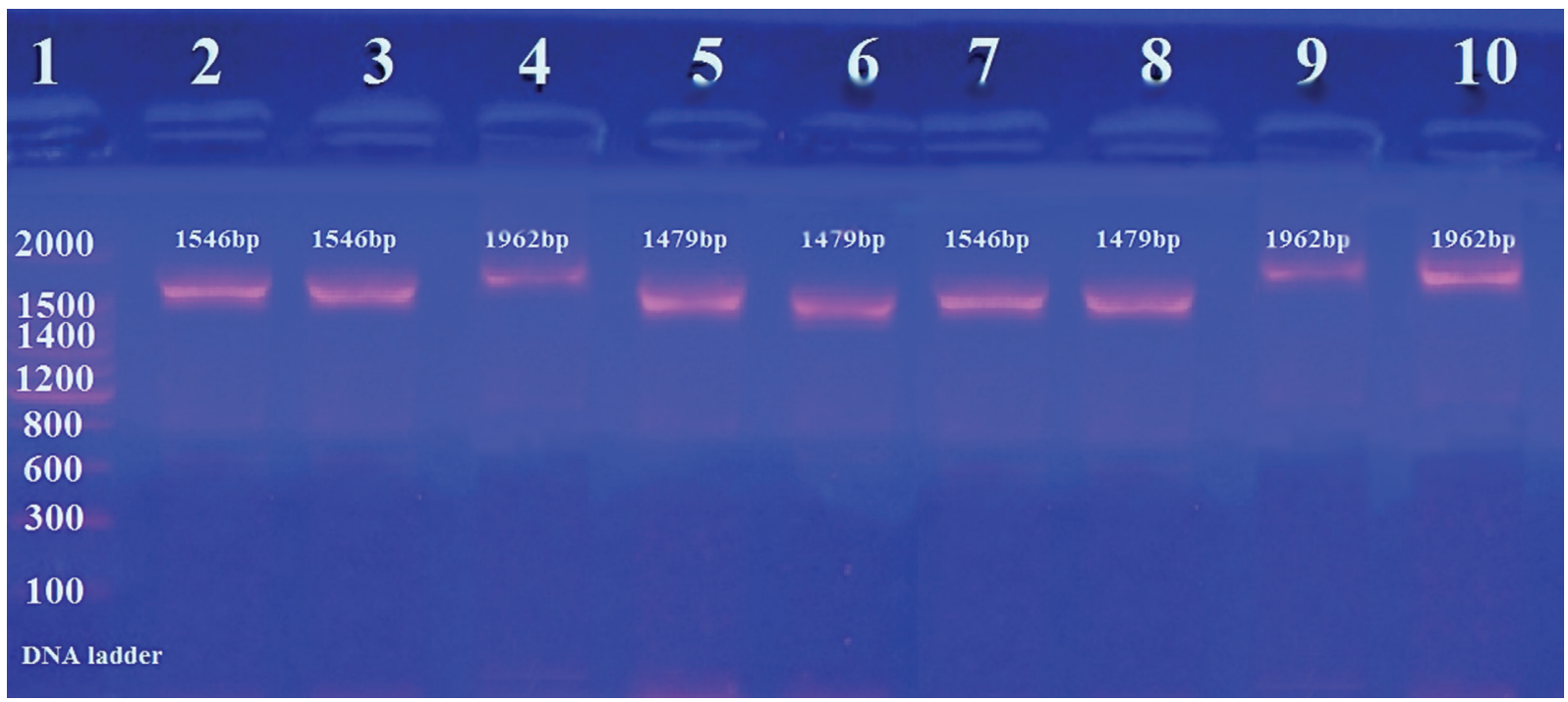

Fig. 2 Gel electrophoresis of amplified DNA from CRC patients by using the primers set CA9, WT1, and PRAME (forward and reversed). Lane 1: DNA ladder. Lanes 2, 3, 7: CRC DNA positive for 1,546 base pairs (bp) (CA9). Lanes 4, 9, 10: CRC DNA positive for 1,962 bp (PRAME). Lanes 5, 6, 8: CRC DNA positive for 1,479 bp (WT1).

the fact that the exact function of the PRAME gene in the tumorigenesis of CRC remains controversial. ${ }^{34}$

The analysis of a very small sample of patients (25 patients with CRC and 10 controls) is a main limitation of the present study; further research with larger samples should be considered to confirm the results found.

\section{Conclusion}

The overexpression of the CA9 gene in CRC of high sensitivity and specificity to be used as a tool for discriminating malignant colorectal tumors from benign since with high accuracy compare with the WT1 and PRAME genes. The diagnostic and prognostic indications of CA9 are more implications to expressed CRC than that of WT1 and PRAME. Furthermore, studies on the molecular mechanisms of the WT1 and PRAME genes are mandatory to provide new information about the function and regulating pathways of these two genes in the tumorigenesis of CRC, since they are expressed, but with low levels of significance. Further research with larger samples should be considered to confirm the results found in the present study. To our knowledge, the present is the first study to report on the importance of the CA9, WT1, and PRAME genes in cases of CRC.

\section{Financial support}

The authors have no sources of funding to declare. 


\section{Conflict of Interests}

The authors have no conflict of interests to declare.

\section{References}

1 Bray F, Ferlay J, Soerjomataram I, Siegel RL, Torre LA, Jemal A. Global cancer statistics 2018: GLOBOCAN estimates of incidence and mortality worldwide for 36 cancers in 185 countries. CA Cancer J Clin 2018;68(06):394-424

2 Alshewered AS, Al-Naqqash MA. Rectal cancer and chemoradiation in Iraq: systematic review and meta-analysis. J Coloproctol (Rio J) 2019;39:309-318

3 Alrubaia AMM, Al-Naqqash MA, Alshewered AS. Epidemiological, and prognostic single-center study of anal carcinoma. J Coloproctol (Rio J) 2020;40(03):202-208

4 Alhilfi HSQ, Almohammadawi KOM, Alsaad RKA, et al. Colorectal cancer epidemiology and clinical study in Misan. J Coloproctol (Rio J) 2019;39(02):159-162

5 Thiry A, Dogné JM, Masereel B, Supuran CT. Targeting tumorassociated carbonic anhydrase IX in cancer therapy. Trends Pharmacol Sci 2006;27(11):566-573

6 Wykoff CC, Beasley NJ, Watson PH, et al. Hypoxia-inducible expression of tumor-associated carbonic anhydrases. Cancer Res 2000;60(24):7075-7083

7 Talvinen K, Tuikkala J, Grönroos J, et al. Biochemical and clinical approaches in evaluating the prognosis of colon cancer. Anticancer Res 2006;26(6C):4745-4751

8 Stauss HJ, Thomas S, Cesco-Gaspere M, et al. WT1-specific T cell receptor gene therapy: improving TCR function in transduced $\mathrm{T}$ cells. Blood Cells Mol Dis 2008;40(01):113-116

9 Algar E. A review of the Wilms' tumor 1 gene (WT1) and its role in hematopoiesis and leukemia. J Hematother Stem Cell Res 2002;11 (04):589-599

10 Oji Y, Ogawa H, Tamaki H, et al. Expression of the Wilms' tumor gene WT1 in solid tumors and its involvement in tumor cell growth. Jpn J Cancer Res 1999;90(02):194-204

11 Inoue $\mathrm{K}$, Sugiyama $\mathrm{H}$, Ogawa $\mathrm{H}$, et al. WT1 as a new prognostic factor and a new marker for the detection of minimal residual disease in acute leukemia. Blood 1994;84(09):3071-3079

12 Loeb DM, Evron E, Patel CB, et al. Wilms' tumor suppressor gene (WT1) is expressed in primary breast tumors despite tumorspecific promoter methylation. Cancer Res 2001;61(03):921-925

13 Miyoshi Y, Ando A, Egawa C, et al. High expression of Wilms' tumor suppressor gene predicts poor prognosis in breast cancer patients. Clin Cancer Res 2002;8(05):1167-1171

14 Oji Y, Miyoshi S, Maeda H, et al. Overexpression of the Wilms' tumor gene WT1 in de novo lung cancers. Int J Cancer 2002;100 (03):297-303

15 Ueda T, Oji Y, Naka N, et al. Overexpression of the Wilms' tumor gene WT1 in human bone and soft-tissue sarcomas. Cancer Sci 2003;94(03):271-276

16 Oji Y, Inohara H, Nakazawa M, et al. Overexpression of the Wilms' tumor gene WT1 in head and neck squamous cell carcinoma. Cancer Sci 2003;94(06):523-529

17 Epping MT, Bernards R. A causal role for the human tumor antigen preferentially expressed antigen of melanoma in cancer. Cancer Res 2006;66(22):10639-10642
18 Miller SA, Dykes DD, Polesky HF. A simple salting out procedure for extracting DNA from human nucleated cells. Nucleic Acids Res 1988;16(03):1215

19 Korinek V, Barker N, Morin PJ, et al. Constitutive transcriptional activation by a beta-catenin-Tcf complex in APC-/- colon carcinoma. Science 1997;275(5307):1784-1787

20 Radhi AA, Muslim OT, Abdlmaged MA. Epidemiological distribution of colorectal cancer in AL-Diwaniyah province, Iraq: an observational study. J Pharm Sci \& Res. 2018;10(07):1758-1760

21 Alsafi RAR, Metib NJ, Hameedi AD, et al. The Clinical and Pathological Characteristics of Colorectal Cancer in Young Age Group in Karbala Province/ Iraq. Karbala J Med. 2018;11(02): 4025-4031

22 Khalil KH, Al-Hassawi BA, Abdo JM. Histopathological evaluation of colorectal carcinoma. Duhok Medical Journal. 2018;12(02): 45-68

23 Al Dahhan SA, Al Lami FH. Epidemiology of Colorectal Cancer in Iraq, 2002-2014. Gulf J Oncolog 2018;1(26):23-26

24 https://www.nice.org.uk/ The National Institute for Health and Care Excellence/guidance/cg131/ colorectal cancer diagnosis and management/ 2014

25 http://publications.iarc.fr/ The International Agency for Research on Cancer/Non-Series-Publications/World cancer report/2014

26 Wang MJ, Ping J, Li Y, et al. The prognostic factors and multiple biomarkers in young patients with colorectal cancer. Sci Rep 2015;5:10645

27 Feitosa MR, de Oliveira THGF, Kondo BRP, et al. The epidemiological and clinical features of familial adenomatous polyposis in Ribeirão Preto. J Coloproctol (Rio J) 2013;33(03):126-130

28 Giatromanolaki A, Koukourakis MI, Sivridis E, et al. Expression of hypoxia-inducible carbonic anhydrase-9 relates to angiogenic pathways and independently to poor outcome in non-small cell lung cancer. Cancer Res 2001;61(21):7992-7998

29 Korkeila E, Talvinen K, Jaakkola PM, et al. Expression of carbonic anhydrase IX suggests poor outcome in rectal cancer. Br J Cancer 2009;100(06):874-880

30 Driessen A, Landuyt W, Pastorekova S, et al. Expression of carbonic anhydrase IX (CA IX), a hypoxia-related protein, rather than vascular-endothelial growth factor (VEGF), a pro-angiogenic factor, correlates with an extremely poor prognosis in esophageal and gastric adenocarcinomas. Ann Surg 2006;243(03): 334-340

31 Oji Y, Yamamoto H, Nomura M, et al. Overexpression of the Wilms' tumor gene WT1 in colorectal adenocarcinoma. Cancer Sci 2003; 94(08):712-717

32 Oberthuer A, Hero B, Spitz R, Berthold F, Fischer M. The tumorassociated antigen PRAME is universally expressed in high-stage neuroblastoma and associated with poor outcome. Clin Cancer Res 2004;10(13):4307-4313

33 Huang Q, Li L, Lin Z, et al. Identification of Preferentially Expressed Antigen of Melanoma as a Potential Tumor Suppressor in Lung Adenocarcinoma. Med Sci Monit 2016;22(22):1837-1842

34 Wadelin F, Fulton J, McEwan PA, Spriggs KA, Emsley J, Heery DM. Leucine-rich repeat protein PRAME: expression, potential functions and clinical implications for leukaemia. Mol Cancer 2010; 9:226 